\title{
Editorial
}

\section{Mudanças na Polímeros}

A partir do próximo número da Polímeros passaremos a contar com o Prof. Sebastião Canevarolo como editor da revista e com a participação no Comitê Editorial do Prof. Covas da Universidade do Minho, Portugal, e do Prof. João B.P. Soares da University of Alberta, Canadá. O Prof. Adhemar Ruvolo atuará ainda como editor interino até julho de 2016, auxiliando o Prof. Canevarolo.

O novo editor assume após o término do mandato de quatro anos da Profa. Elisabete Frollini. O Conselho Editorial agradece o trabalho da Profa. Elisabete, que atuou firmemente como editora e promoveu, juntamente com o Comitê Editorial, muitas melhorias importantes na revista, sendo elas: a mudança do formato da versão impressa, a criação do template, a implementação da predominância de artigos em inglês, o site em inglês e o início do processo de migração do sistema de submissão para a plataforma ScholarOne.

A decisão do Comitê Editorial pela predominância de artigos em inglês visava a maior internacionalização de nossa revista e resultou em um aumento considerável nos acessos aos artigos por pessoas do exterior. Como consequência disso, o Conselho Editorial, em sua reunião durante o CBPol, oficializou a decisão da revista passar, a partir de outubro de 2015, a processar somente os artigos redigidos em inglês e no formato do template. Além disso, já em janeiro de 2016 deveremos estar recebendo todas as submissões pelo site da revista na plataforma ScholarOne. Esperamos em 2016 ter publicado todos os artigos em português que foram submetidos/aceitos até setembro de 2015, passando então a ter uma revista inteiramente em inglês. Todas essas medidas visam atender os padrões exigidos pela plataforma ScholarOne e, naturalmente, melhorar ainda mais o nível técnico/científico da Polímeros.

Em 2015 a revista teve apoio financeiro direto somente do CNPq e indireto da FAPERGS, o que causou uma redução considerável nos recursos disponíveis para a revista. Como consequência disso, a Diretoria e Conselho da ABPol, em sua última reunião, autorizaram o uso de fundos próprios da associação para a finalização dos números de 2015. Além disso, a Diretoria e Conselho da ABPol decidiram, e o Conselho Editorial referendou, que a revista deixasse de ser impressa, passando a ser acessada exclusivamente pela internet. Com isso reduziremos consideravelmente os custos da revista e aumentaremos a sua visibilidade. Em futuro próximo os sócios da ABPol receberão os números da revista na forma de uma mensagem eletrônica, com o expediente e o índice dos trabalhos com um link para cada artigo em versão pdf. Apesar dessas medidas, a saúde financeira da Polímeros ainda é uma incógnita para 2016

Professor Marco-Aurelio De Paoli
Presidente do Conselho Editorial 